\title{
Awareness levels on personal hygiene and morbidity profile of tribal children
}

\section{Deepa and V. Vijayalakshmi}

Received: 13.11.2018; Revised: 13.04.2019; Accepted: 23.04.2019

See end of the paper for authors' affiliations

\section{Deepa}

Krishi Vigyan Kendra, Guntur (A.P.) India

Email : deepanarayana@

rediffmail.com
ABSTRACT : Mahabubnagar district of Telangana state was selected for the study, to study the awareness levels of tribal families on personal hygiene and morbidity profile of tribal families. Purposive random sampling technique was used to select the sample. Sample comprised of 125 tribal families, total 125 men and 125 women were selected for the study. Tribal couples in the age group of $18-30$ years were selected for the study. Awareness levels on personal hygiene was studied by using interview schedule developed for the study. Results of the study revealed that tribal families lack awareness on spreading of diseases through contaminated water and food. stomach infections and frequent fevers was common among tribals. Awareness on food contamination and contagious diseases was found to be low among tribal families, this could also one of the reason for frequent stomach infections among tribal families.

KEY WORDS: Personal hygiene, Morbidity profile, Tribal children

- HOW TO CITE THIS PAPER : Deepa, M. and Vijayalakshmi, V. (2019). Awareness levels on personal hygiene and morbidity profile of tribal children. Asian J. Home Sci., 14 (1) : 69-71, DOI: 10.15740/HAS/ AJHS/14.1/69-71. Copyright@ 2019: Hind Agri-Horticultural Society. 